\title{
Optimization of Raw Ewes' Milk High-Pressure Pre-Treatment for Improved Production of Raw Milk Cheese
}

\author{
Rita S. Inácio ${ }^{1,2,3}$, Rui Barros ${ }^{2}\left(\mathbb{C}\right.$, Jorge A. Saraiva ${ }^{3, *}$ and Ana M. P. Gomes ${ }^{2, *(1)}$ \\ 1 Department of Applied Technologies and Sciences, School of Agriculture, Polytechnic Institute of Beja, \\ 7800-295 Beja, Portugal; rita.inacio@ipbeja.pt \\ 2 CBQF-Centro de Biotecnologia e Química Fina-Laboratório Associado, Escola Superior de Biotecnologia, \\ Universidade Católica Portuguesa, Rua Diogo Botelho 1327, 4169-005 Porto, Portugal; rbarros@porto.ucp.pt \\ 3 LAQV-REQUIMTE-Laboratório Associado, Department of Chemistry, Campus Universitário de Santiago, \\ University of Aveiro, 3810-193 Aveiro, Portugal \\ * Correspondence: jorgesaraiva@ua.pt (J.A.S.); amgomes@porto.ucp.pt (A.M.P.G.)
}

Citation: Inácio, R.S.; Barros, R.; Saraiva, J.A.; Gomes, A.M.P. Optimization of Raw Ewes' Milk High-Pressure Pre-Treatment for Improved Production of Raw Milk Cheese. Foods 2022, 11, 435. https:// doi.org/10.3390/foods11030435

Academic Editors: Anet Režek Jambrak and Krystian Marszałek

Received: 30 December 2021

Accepted: 28 January 2022

Published: 1 February 2022

Publisher's Note: MDPI stays neutral with regard to jurisdictional claims in published maps and institutional affiliations.

Copyright: (C) 2022 by the authors. Licensee MDPI, Basel, Switzerland. This article is an open access article distributed under the terms and conditions of the Creative Commons Attribution (CC BY) license (https:// creativecommons.org/licenses/by/ $4.0 /)$.

\begin{abstract}
Serra da Estrela protected designation of origin (PDO) cheese is manufactured with raw milk from Bordaleira and/or Churra Mondegueira da Serra da Estrela sheep breeds. Several socioenvironmental shortcomings have reduced production capacity; hence, treatments that may contribute to its efficient transformation into cheese are welcome. High-pressure processing (HPP) milk pre-treatment may contribute to a cheese yield increment, yet optimization of processing conditions is warranted. An initial wide-scope screening experiment allowed for pinpointing pressure intensity, holding time under pressure and time after HPP as the most important factors influencing curd yield. Based on this, a more targeted screening experiment allowed for selecting the range of experimental conditions to be used for an experimental design study that revealed an HPP treatment at $121 \mathrm{MPa}$ for $30 \mathrm{~min}$ as the optimum for milk processing to improve curd yield ( $>9 \%)$ and effectively maintain the beneficial cheese microbiota; the optimum was validated in a final experimental framework.
\end{abstract}

Keywords: design of experiment; Serra da Estrela cheese; microbial composition; yield; safety; high-pressure processing; experimental screening

\section{Introduction}

In cheesemaking, the cheese yield ( $\mathrm{kg}$ cheese $/ \mathrm{kg}$ milk) is of particular economic interest since small differences in yield translate into big differences in both milk volume savings and final profits; the higher the solids percentage recovered, the greater the amount of cheese obtained, thus reflecting economic gains. In the particular case of the protected designation of origin (PDO) Serra da Estrela ewe cheese, the available milk is becoming scarcer due to limitations of various kinds, such as environmental and social cues. Serra da Estrela cheese is made solely with milk from Bordaleira Serra da Estrela and/or Churra Mondegueira ewe breeds, and according to specifications the milk cannot undergo any thermal treatment [1-3].

High-pressure processing (HPP) is a non-thermal food processing technology, wherein the food is subjected to a very high pressure range from 100-800 MPa during a holding period between 5-60 min. Different literature reports have indicated that HPP milk pretreatment can increase curd yield [4,5]. Moreover, milk HPP has the potential to reduce viable cell numbers of undesirable contaminant micro-organisms, without significant effects on flavour and nutritional components, contributing to safer high-quality cheese products; however, HPP may influence the physicochemical and technological properties of the milk [6-8]. The effect of HPP on the curd yield has been evaluated mainly in cows' milk [4,5,9-11] and goats' milk [12-14], while only a few studies have focused on ewes' milk $[13,14]$. In general, milk HPP pre-treatments have enabled an increase of the curd yield from about $4-23 \%$ in comparison to untreated milk. Huppertz et al. (2005) studied cow milk 
HPP pre-treatment between 100 and $600 \mathrm{MPa}$, having verified higher yield values (13-18\%) at 100 and $250 \mathrm{MPa}$. On the other hand, one year before, the same group had verified lower values for HPP-treated milk at $250 \mathrm{MPa}$ (exception for treatment for 60 min with $4 \%$ yield increasing) and higher values for HPP treatment at 400 and $600 \mathrm{MPa}(4-23 \%)$ [5]. Furthermore, higher cow curd yield values were verified after maintaining the milk at $20{ }^{\circ} \mathrm{C}$ for $24 \mathrm{~h}$ post HPP treatment [5]. The same study revealed that a longer holding time under pressure (from 5 to $30 \mathrm{~min}$ ) also increased the curd yield. In ewes' milk, HPP treatments at $100 \mathrm{MPa}$ for $30 \mathrm{~min}$ revealed a similar yield compared to untreated milk and an increase of about 5, 5 and 16\% for 200, 300 and $400 \mathrm{MPa}$, respectively [13]. Ewes' milk HPP treatment at $300 \mathrm{MPa}$ with a holding time of 10,20 and 30 min showed similar yield values but lower values when processing was for $5 \mathrm{~min}$ [13]. Similar results were verified in a further study by the same research group; López-Fandiño and Olano (1998) observed a higher yield after HPP at $40{ }^{\circ} \mathrm{C}$ than at $25{ }^{\circ} \mathrm{C}$ (about $23 \%$ vs. $9 \%$ ) but reported that such treatment caused deleterious effects on gel firmness.

Several questions remain unanswered; hence, the main objectives of the current research were to use design of experiments (DoE) and response surface methodology (RSM) to determine the optimum HPP milk pre-treatment conditions that maximize curd yield while maintaining the beneficial microbiota of the cheese at most desirable levels for cheese biochemical properties development.

\section{Materials and Methods}

\subsection{Screening Experimental Design and Rationale for Choice of Conditions}

Firstly, an initial wide screening study, two level full factorial design in triplicate for four factors $\left(24=16^{*} 3=48\right.$ runs-see Table 1$)$, was performed, in a randomized order, to identify the variables/factors with main effect and the interaction of factors on Serra da Estrela curd yield and time of coagulation. Based on previous studies in the literature, the four variables selected were: pressure intensity (range 200-400 MPa), holding time under pressure (range 5-60 min), time before HPP (1-48 h) and time after HPP (1-24 h), as shown in Figure 1. The waiting time before HPP and after HPP allowed for understanding if the storage time of milk prior to HPP and after HPP treatment influenced curd yield. The outcome parameters measured were yield and coagulation time. At the same time, untreated milk was studied as a control in order to compare with HPP-treated milk.

Table 1. Factors and levels for the initial wide screening and focused screening studies and optimization design of experiment (HPP stands for high-pressure processing).

\begin{tabular}{|c|c|c|c|}
\hline Factors & Level $(-1)$ & Level (0) & Level $(+1)$ \\
\hline \multicolumn{4}{|c|}{ Wide screening study: two level full factorial design } \\
\hline Pressure intensity (MPa) & 200 & & 400 \\
\hline Holding time (min) & 5 & & 30 \\
\hline Before HPP time $(\mathrm{h})$ & 1 & & 48 \\
\hline After HPP time (h) & 1 & & 24 \\
\hline \multicolumn{4}{|c|}{ Focused screening study } \\
\hline Pressure intensity (MPa) & 100 & & 400 \\
\hline Holding time (min) & 5 & & \\
\hline Before HPP time $(\mathrm{h})$ & & & 48 \\
\hline After HPP time (h) & & & 24 \\
\hline \multicolumn{4}{|c|}{ Optimization design of Experiment: central composite design } \\
\hline Pressure intensity (MPa) & 100 & 200 & 300 \\
\hline Holding time (min) & 5 & 17.5 & 30 \\
\hline Before HPP time (h) & & 24 & \\
\hline After HPP time (h) & & & 24 \\
\hline
\end{tabular}




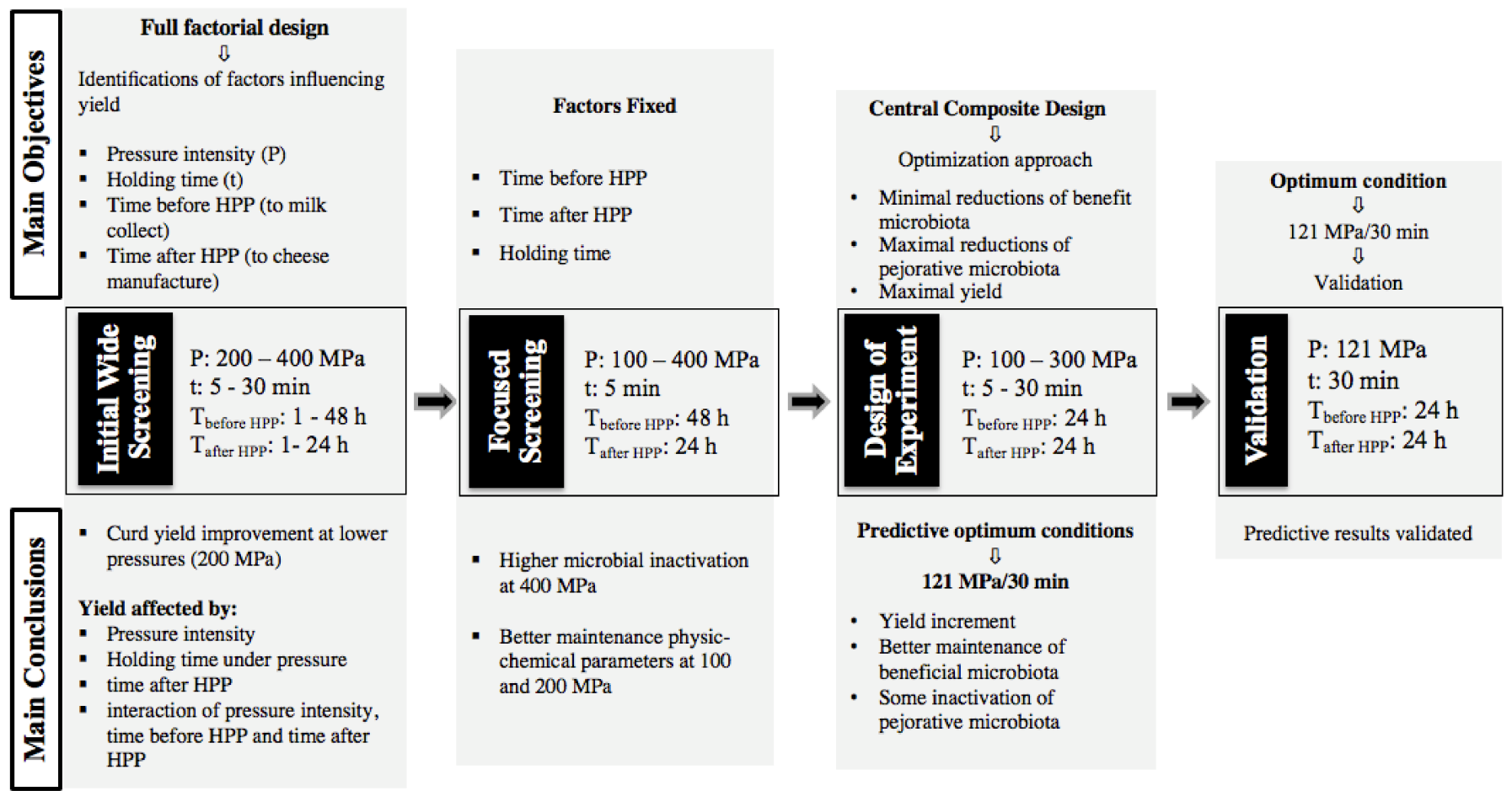

Figure 1. Schematic representation of initial wide screening, focused screening, design of experiment and validation.

Considering that the results of this initial wide screening study revealed more interesting results for lower pressures, $100 \mathrm{MPa}$ was also studied, and the processing time was fixed at $5 \mathrm{~min}$, because the processing time was found to have minor effect; further analyses were also carried out, namely $\mathrm{pH}$, titratable acidity and microbiological enumeration.

\subsection{Surface Model—Optimization Experimental Design-Central Composite Design}

Upon selection of the most important factors in the initial wide and the focused studies, an optimization design for curd yield improvement was established using a central composite design (Figure 1). This design consisted of a factorial design with two factors at two levels: pressure intensity ranged between 100-300 MPa and holding time under pressure between 5-30 min; additional axial and 5 central points were considered, as shown in Table 1, and dependent variables were technological cheese parameters (curd yield and coagulation time) and milk microbiota viable cell numbers (lactococci, lactobacilli, enterococci, Enterobacteriaceae, total coliforms, E. coli, staphylococci, yeasts and moulds counts).

\subsection{Validation Experiment Design}

The theoretical optimum conditions $121 \mathrm{MPa} / 30 \mathrm{~min}$ (obtained for the optimization experiment design) were applied to raw ewes' milk samples in a validation experiment in quintuplicate for greater validation robustness (untreated milk was also studied for data normalization).

\subsection{Milk Supply}

Raw ewes' milk (from three farms in Serra da Estrela cheese PDO region, Portugal) was kept in a refrigerated tank until use, and prior to sampling milk was well mixed to ensure a homogeneous sample. Five litres of milk were used for the initial wide screening and another $5 \mathrm{~L}$ for the focused screening experiments, which were performed in December and January, respectively. For the response surface design, $8 \mathrm{~L}$ of milk was used in February and another $8 \mathrm{~L}$ in March for the model validation. 


\subsection{Sample Packaging}

In the dairy, milk aliquots $(\approx 75 \mathrm{~mL})$ were placed into polyamide-polyethylene (PAPE) bags (Plásticos Macar-Indústria de Plásticos Lda, Santo Tirso, Portugal) and heat sealed. The milk bags were stored under refrigeration $\left(4^{\circ} \mathrm{C}\right)$ before and after HPP treatment until analysis.

\subsection{High-Pressure Processing}

HPP was performed in $55 \mathrm{~L}$ capacity industrial scale high-pressure equipment (model 55, Hyperbaric, Burgos, Spain). For all experiments, the initial temperature of the water used as transmitting fluid was $8^{\circ} \mathrm{C}$. For the initial wide screening study: HPP was performed on the day of milk collection and after $48 \mathrm{~h}$, as shown in Table 1 and Figure 1, the milk having been treated at 200 and $400 \mathrm{MPa}$ for 5 and $30 \mathrm{~min}$. For the focused screening study: the milk was treated after $48 \mathrm{~h}$ of collection and the curd transformation occurred after $24 \mathrm{~h}$ of HPP treatment, and milk samples were treated at 100, 200, 300 and $400 \mathrm{MPa}$ for $5 \mathrm{~min}$. For design of experiment, the milk was treated after $24 \mathrm{~h}$ of collection and the curd transformation occurred after $24 \mathrm{~h}$ of HPP treatment, according to Table 1 . The validation step occurred using the optimum HPP conditions obtained in the design of experiment study, i.e., $121 \mathrm{MPa}$ for $30 \mathrm{~min}$.

\subsection{Yield and Coagulation Time}

Yield was estimated by centrifugation. Prewarmed milk ( $30 \mathrm{~mL})$ to $32{ }^{\circ} \mathrm{C}$ was treated with $50 \mu \mathrm{L}$ of standard vegetable rennet (Cyanara cardunculus, strength 1:15,000, Enzilab, Maia, Portugal). After $1 \mathrm{~h}$ at $32^{\circ} \mathrm{C}$, the curd was cut and $10 \mathrm{~min}$ later centrifuged at $1500 \times g$ for $15 \mathrm{~min}$ at $5^{\circ} \mathrm{C}$. The curd and whey were then separated and weighed. Coagulation time was evaluated by placing a spatula in the tubes every $10 \mathrm{~min}$ to see when the spatula came out of the curd free of any curd granules.

\subsection{Microbiological Analyses}

Milk samples were added to and decimally diluted in $13.5 \mathrm{~mL}$ of sterile $0.1 \%(w / v)$ aqueous peptone and then plated, in triplicate, on several culture media. The following microbial groups were enumerated using the pour plate method: Enterobacteriaceae on violet red bile dextrose agar (VRBDA from Merck, Germany) and coliforms and E. coli on Chromocult coliform agar (CCA from Merck), both incubated at $37{ }^{\circ} \mathrm{C}$ for $1 \mathrm{~d}$. The Miles and Misra technique [15] was used for enumeration of: total aerobic mesophilic micro-organisms on plate count agar (PCA from Merck) and incubated at $30{ }^{\circ} \mathrm{C}$ for $3 \mathrm{~d}$; Enterococcus spp. on kanamycin aesculin azide agar base (KAAA from Oxoid, UK) and incubated at $37^{\circ} \mathrm{C}$ for $1 \mathrm{~d}$; Lactobacillus spp. on Man, Rogosa and Sharpe (MRS from Merck) and incubated at $30^{\circ} \mathrm{C}$ for $3 \mathrm{~d}$; Lactococcus spp. on M17 (Liofilchem, Roseto degli Abruzzi, Italy) and incubated at $30{ }^{\circ} \mathrm{C}$ for $3 \mathrm{~d}$; Staphylococcus spp. on Baird-Parker agar (BPA from Merck) with egg yolk tellurite emulsion (Liofilchem) and incubated at $37^{\circ} \mathrm{C}$ for $2 \mathrm{~d}$; Listeria spp. on PALCAM agar selective agar base (Liofilchem), with selective supplement for PALCAM (Liofilchem) and incubated at $37^{\circ} \mathrm{C}$ for $2 \mathrm{~d}$; Pseudomonas spp. on pseudomonas agar base (PAB from Liofilchem) with glycerol and pseudomonas CFC supplement (CFC from Liofilchem) and incubated at $30^{\circ} \mathrm{C}$ for $2 \mathrm{~d}$. Petri dishes containing 10-100 colony forming units ( $\mathrm{cfu}$ ) were selected for counting. The results were converted into logarithmic decimals of the number of cfu per $\mathrm{mL}$ of milk.

\subsection{Physicochemical Analyses}

The $\mathrm{pH}$ values of the milk and cheese were measured, at room temperature, in random points using a properly calibrated $\mathrm{pH}$ /temperature penetration $\mathrm{pH}$ meter (Testo 205, Testo, Inc., Sparta, NJ, USA). The titratable acidity was determined according to AOAC 947.05 [16] procedure for milk, using an automatic titrator with $\mathrm{pH}$ meter (Crison TitroMatic 1S with $\mathrm{pH}$ electrode 5.14, Barcelona, Spain), by titration to a $\mathrm{pH}$ value of 8.9. Physicochemical analyses were performed in triplicate per milk and cheese samples. 


\subsection{Colour}

Colour parameters were measured using a Minolta Konica CM-2300d (Konica Minolta CM-2300d, Osaka, Japan) at room temperature. The colour parameters were recorded in CIE Lab system and directly computed through the original SpectraMagic NX software (Konica Minolta, Osaka, Japan), according to the International Commission on Illumination regulations. Milk samples were kept $1 \mathrm{~h}$ at room temperature before measurements. Measurements were performed selecting six random spots, read in triplicate.

\subsection{Statistical Analyses}

For experimental design, Minitab and JMP software were used. SPSS software version 26.0 was used to evaluate the effect of factors and interactions in the initial wide screening study. For the focused screening, one-way analysis variance (ANOVA) was performed to establish the effect of different conditions (for HPP and untreated milk). The significant difference Tukey's test was applied to compare the mean values of parameters, with the significance assigned at $p<0.05$.

\section{Results and Discussion}

\subsection{Initial Wide Screening Study}

In order to identify which factors may influence curd yield, a full factorial design was chosen where all possible combinations of all the input variables and their levels were included (Table 1 and Figure 1). Immediately after HPP treatment, the milk processed at $200 \mathrm{MPa}$ was still liquid; however, the milk treated at $400 \mathrm{MPa}$ revealed a more viscous texture, and after $24 \mathrm{~h}$ under refrigeration these samples revealed curd and whey separation. In the literature, a linear increase in skim milk viscosity was verified after HPP between 100 and $400 \mathrm{MPa}$ for 30 min by Thom Huppertz, Fox and Kelly (2003).

In general, firmer curds were obtained from HPP processed milk for 5 min, while the milk treated for $30 \mathrm{~min}$ resulted in a curd/paste similar to a granular whey cheese (Figure S1). Rosina López-Fandiño, Mercedes Ramos and Olano (1997) also verified higher curd firmness for cow HPP-treated milk for 10 rather than for $30 \mathrm{~min}$ at $400 \mathrm{MPa}$. Results in the literature indicate that, for ewes' milk, curd firmness was not affected by the HPP conditions (100-400 MPa for $30 \mathrm{~min}$ ), while for goats' milk firmness increased at 300 and $400 \mathrm{MPa}$ [13]. In the present study, control samples revealed intermediate firmness compared to the HPP-treated samples. Faster coagulation occurred in HPP-treated milk at $400 \mathrm{MPa}$, particularly for a $30 \mathrm{~min}$ holding time (Figure 2A). The effect of HPP milk pre-treatment on coagulation time has been reported in the literature as being mainly dependent of pressure intensity and holding time. In this regard, a research group in this dominion treated bovine milk by HPP using different binomial pressure intensity/holding times $[14,17,18]$. These researchers were able to verify a reduction in coagulation time for HPP up to $200 \mathrm{MPa}$ with treatment times within the range 10-60 min, while HPP treatment at $400 \mathrm{MPa}$ only registered lower coagulation time when applied for $10 \mathrm{~min}$; longer HPP holding times under such pressure increased coagulation time to values close to those of unprocessed milk. In a study performed with ovine milk, authors achieved results that support those presented in the current study; they were able to show that coagulation time decreased slightly after HPP $100 \mathrm{MPa}$ for $30 \mathrm{~min}$ and increased significantly after $\mathrm{HPP}$ at 200-300 MPa to values 14-28\% higher than untreated milk samples, albeit a new decrease for HPP at $400 \mathrm{MPa}$, although to values that remained slightly higher than those for untreated milk. Notably, gel firmness was not affected in the whole range of pressure studied (100-400 MPa) [13]. 


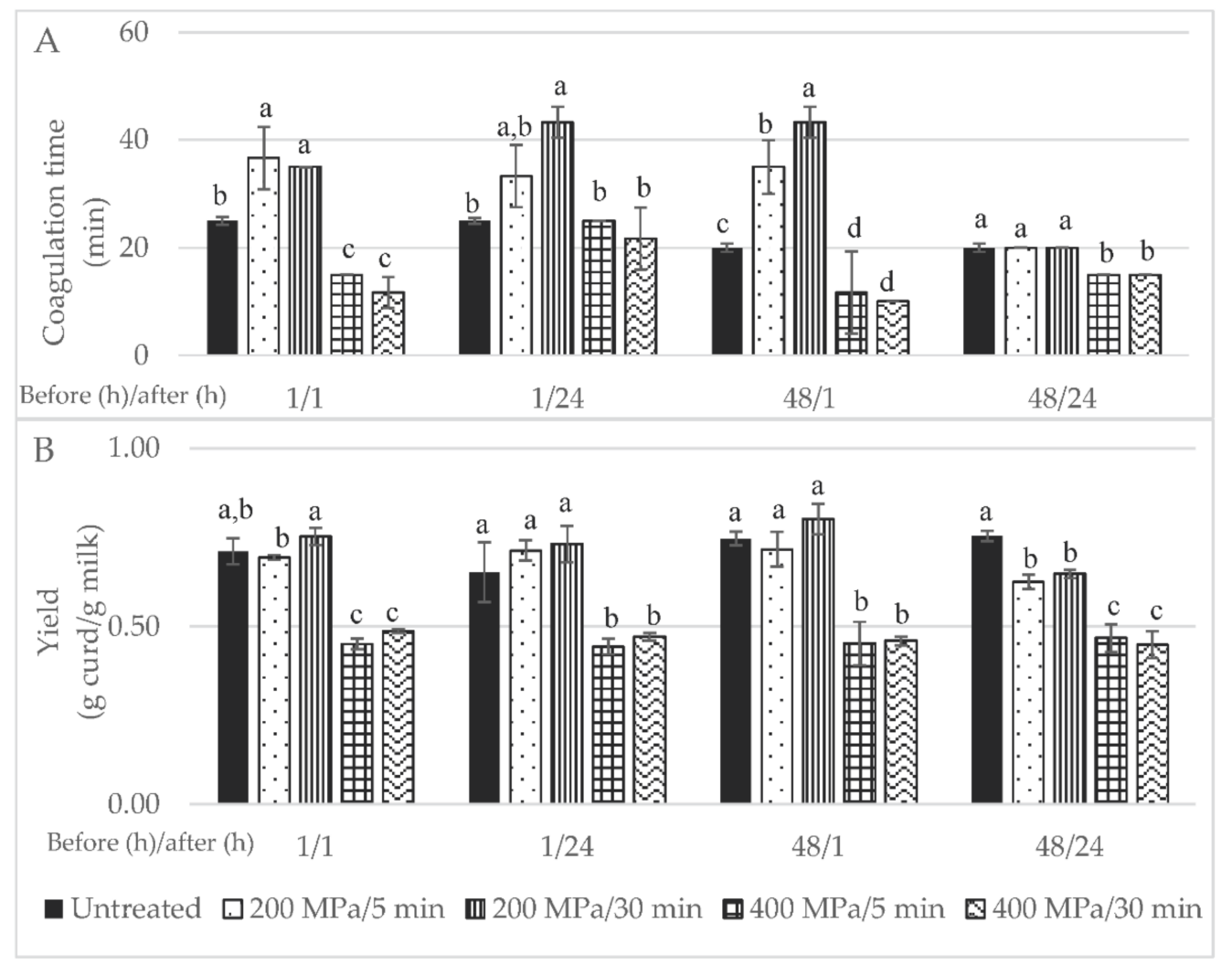

Figure 2. Initial wide screening results for: (A) coagulation time (in min) and (B) yield expressed in $\mathrm{g}$ of curd per g of milk; 1/1-milk high-pressure processing (HPP)-treated and transformed within the day of collection; 1/24-milk HPP-treated on day of collection and transformed the next day; 48/1-milk HPP-treated after $48 \mathrm{~h}$ of collection and subsequently transformed on the same day; 48/24-milk HPP-treated after $48 \mathrm{~h}$ of collection and transformed after $24 \mathrm{~h}$; control samples are untreated milk. Different non-capital letters $(a, b, c)$ indicate statistically significant differences for the same waiting time $(p<0.05)$ between treatment conditions.

The timespan between HPP treatment and milk transformation into curd could also be a factor influencing coagulation time. In the present study, a lower coagulation time was verified when milk was transformed immediately into curd compared to curd production after $24 \mathrm{~h}$ storage of the HPP-treated milk under refrigeration (Figure 2). Zobrist, Huppertz, Uniacke, Fox and Kelly, (2005) [19] also reported a lower coagulation time for cows' milk stored for short (after 0 and $4 \mathrm{~h}$ ) than for long periods (after 24 and $48 \mathrm{~h}$ ). This might be related to the fact that HPP leads to an increase in size and number of casein micelles, due to weakening of hydrophobic and electrostatic interactions between submicelles and further aggregation of submicelles to bigger clusters, with changes to form chains or clusters of submicelles ([6] cited in [20]).

Syneresis occurred only in those cheeses manufactured from HPP milk treated at the lower pressure under study (200 MPa) and also in control cheeses (see Figure S1). Low syneresis was reported in the literature for milk HPP-treated at higher intensity, e.g., treatments at $676 \mathrm{MPa} / 5 \mathrm{~min}$ at $10{ }^{\circ} \mathrm{C}$ for bovine milk [10], 600/15 min for skim milk [21], while treatments at 200 and 400 did not show significant differences [21].

Yield was improved by milk HPP pre-treatment at $200 \mathrm{MPa}$, as shown in Figure 2B; in particular, when the milk was treated for $30 \mathrm{~min}$, after $48 \mathrm{~h}$ of refrigeration upon collection and transformation $1 \mathrm{~h}$ after HPP, a $12 \%$ increase in yield was achieved $(p>0.05)$. In contrast to what has been reported in the literature $[5,13]$, in this study the milk HPP treatment at higher pressure intensity, i.e., $400 \mathrm{MPa}$, led to lower curd yields. Huppertz et al. (2004) reported a higher yield for cheeses made from HPP-treated cows' milk (100-400 MPa) upon storage for $24 \mathrm{~h}$ at $20^{\circ} \mathrm{C}$ than those produced immediately after HPP milk treatment. 
Furthermore, a higher curd formation yield was obtained with ewes' milk HPP-treated at $200 \mathrm{MPa} / 30 \mathrm{~min}$ than with the control milk (11\%); nevertheless, a considerable increase in curd yield was achieved after milk was HPP-treated at $400 \mathrm{MPa} / 30 \mathrm{~min}(15.6 \%)$ [13]. A similar HPP treatment (400 MPa/30 min) on cows' milk led to a curd yield increase of $20 \%$ [18]. The increase in curd/cheese yield may be due to greater moisture retention but also to the incorporation of some denatured B-lactoglobulin [18].

Statistical analysis of the data showed that the curd yield was affected by the pressure intensity $(p<0.001)$, holding time under pressure $(p<0.05)$, time after HPP $(p<0.05)$ as single factors and by the interaction of pressure intensity time before HPP and time after HPP $(p<0.001)$. This first step, i.e., the initial wide screening design, was crucial to determine that the pressure intensity, holding time under pressure and time after HPP were the most important factors when curd yield increment was desired. To the best of our knowledge, this is the first research work where all four factors and their interactions were studied for milk; furthermore, only Zobrist et al. (2005) studied the effect of cows' milk storage after HPP and prior to rennet addition on coagulation time, having also verified different coagulation times after different milk HPP storage times of 4,24 and $48 \mathrm{~h}$ at 4 and $20{ }^{\circ} \mathrm{C}$.

Based on the results obtained in the wide screening study and discussed above, milk refrigerated storage before and after HPP treatment was fixed at 48 and $24 \mathrm{~h}$, respectively, since the time before HPP showed no individual effects on curd yield.

\subsection{Focused Screening Design}

As mentioned above, the initial wide screening design revealed more interesting results in milk HPP pre-treated at low pressure intensity (200 $\mathrm{MPa}$ ) than at high pressure intensity (400 MPa). Therefore, in order to rule out any possibility of lower pressures bringing on more favourable results, in the focused screening design, the range of pressure intensity was widened to include also $100 \mathrm{MPa}$, and additional analyses were also carried out, namely $\mathrm{pH}$, titratable acidity and microbiological data.

As in the previous screening, HPP-treated milk at lower pressures, i.e., 100 and $200 \mathrm{MPa}$, remained in its liquid form, and the milk treated at 300 and $400 \mathrm{MPa}$ became viscous and yellower and presented phase separation with time (Figure S2). This visual analysis is in agreement with the obtained curds (Figure S3) and milk pH values measured, as shown in Figure 3A. HPP-treated milk at 300 and $400 \mathrm{MPa}$ revealed significantly higher $\mathrm{pH}$ values (6.38 and 6.42, respectively) than the control milk (5.74) $(p<0.001)$. Closer to the $\mathrm{pH}$ values of control milk were those of milk HPP-treated at 100 and $200 \mathrm{MPa}(5.81$ and 5.89), although statistically different $(p<0.001)$. In the literature, HPP goat milk treatment (500 MPa/15 min) led to significantly higher milk pH values in comparison to thermally pasteurized milk (6.66 vs. 6.54, respectively) [12]. Raw whole bovine milk revealed a similar effect, with $\mathrm{HPP}$ treatments $(100,250$ and $400 \mathrm{MPa} / 15 \mathrm{~min})$ inducing increments in milk pH values (to 6.73-6.75 vs. 6.66 of control milk) but without significant differences among HPP treatments [19]. These $\mathrm{pH}$ changes brought about by HPP can be due to dissolution of colloidal calcium phosphate (CCP), due to its dissociation from the casein micelle [22], possibly due to weakening of hydrophobic and electrostatic interactions between submicelles. 


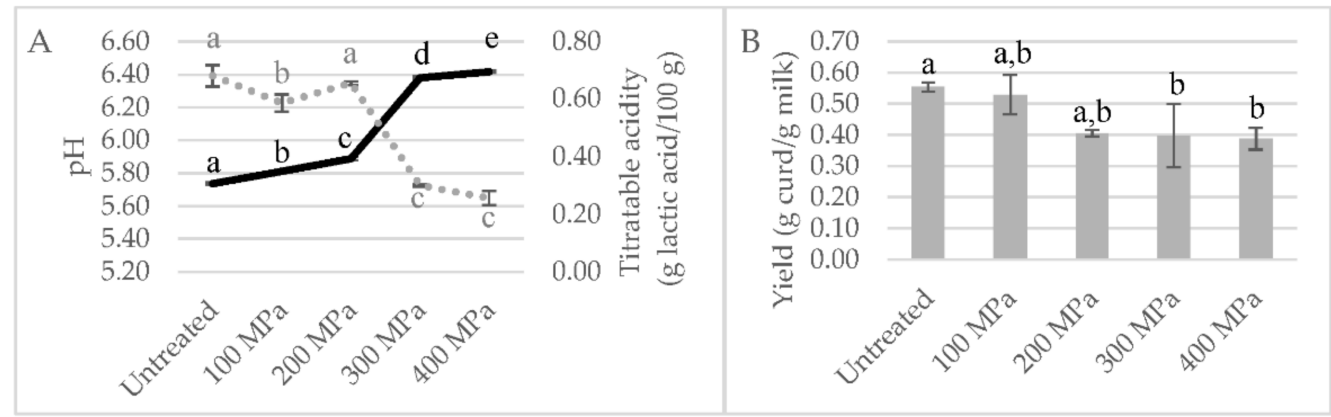

Figure 3. Focused screening study results: (A) milk pH values (continuous line) and titratable acidity (dots line); (B) yield expressed in g of curd per g of high-pressure processing (HPP)-treated milk at 100, 200, 300 and $400 \mathrm{MPa}$ for $5 \mathrm{~min}$ after $48 \mathrm{~h}$ of collection and transformed after $24 \mathrm{~h}$ storage. Different non-capital letters $(a, b, c, d, e)$ indicate statistically significant differences between the different conditions $(p<0.05)$.

Titratable acidity was in agreement with the changes in $\mathrm{pH}$ values (Figure 3A). Relative to the curd yield, similar values were obtained for milk HPP-treated at $100 \mathrm{MPa}$ and untreated milk ( $p>0.05)$ ( 0.55 vs. $0.53 \mathrm{~g}$ milk/g curd), as shown in Figure 3B.

As expected, HPP treatment at $400 \mathrm{MPa}$ strongly affected microbial cell viability, in particular the beneficial microbiota that contribute positively to the cheese ripening process. On the other hand, many of the microbial groups tested, namely lactobacilli, enterococci, total mesophilic micro-organisms, staphylococci, coliforms and Enterobacteriaceae counts, were only slightly affected when milk was treated at $100 \mathrm{MPa}$ (data not shown). Thus, a lower pressure intensity kept the beneficial microbiota and could improve the yield, but the minimization of spoilage bacteria such as staphylococci, coliforms and Enterobacteriaceae was not successfully achieved.

\subsection{Optimization Design of Experiment by Central Composite Design}

Based on the results obtained in the two screening studies, an optimization approach followed, where the factors to be studied included pressure intensity between 100 and $300 \mathrm{MPa}$, time of HPP treatment between 5 to $30 \mathrm{~min}$ (Table 1 and Figure 1), after $24 \mathrm{~h}$ of milk collection (note that this time period was reduced due to high viable cell numbers quantified in the focused screening design) and curd transformed after $24 \mathrm{~h}$ of HPP treatment.

Visual analysis of the milk bags upon treatment revealed that samples treated at $300 \mathrm{MPa}$ for 5, 30 and $17.5 \mathrm{~min}$ (samples 3, 4 and 6, respectively, in Figure S4) were yellower. Instrumental colour analysis confirmed these colour variations, since these HPP-treated milks revealed higher $b^{*}$-values (Figure 4); Gervilla, Ferragut and Guamis (2001) reported similar results for HPP-treated (100-300 MPa/15 min) raw ewes' milk where an increase of $b^{*}$-values was observed. Overall, HPP treatments at higher pressure intensity (200 and $300 \mathrm{MPa}$ ) led to a yellower milk colour (higher $b^{*}$-values), particularly for longer holding times under pressure (17.5 and $30 \mathrm{~min}$ ). Higher $L^{*}$-values were measured for HPP-treated milk at $100 \mathrm{MPa}$ for 5 and $17.5 \mathrm{~min}$, while the other treatments led to similar or slightly lower $L^{*}$-values than the control milk. The literature reports that HPP induces changes in $L^{*}$-values mainly due to casein micelles disintegration into small fragments that increase the milk translucidity [23-25]. 


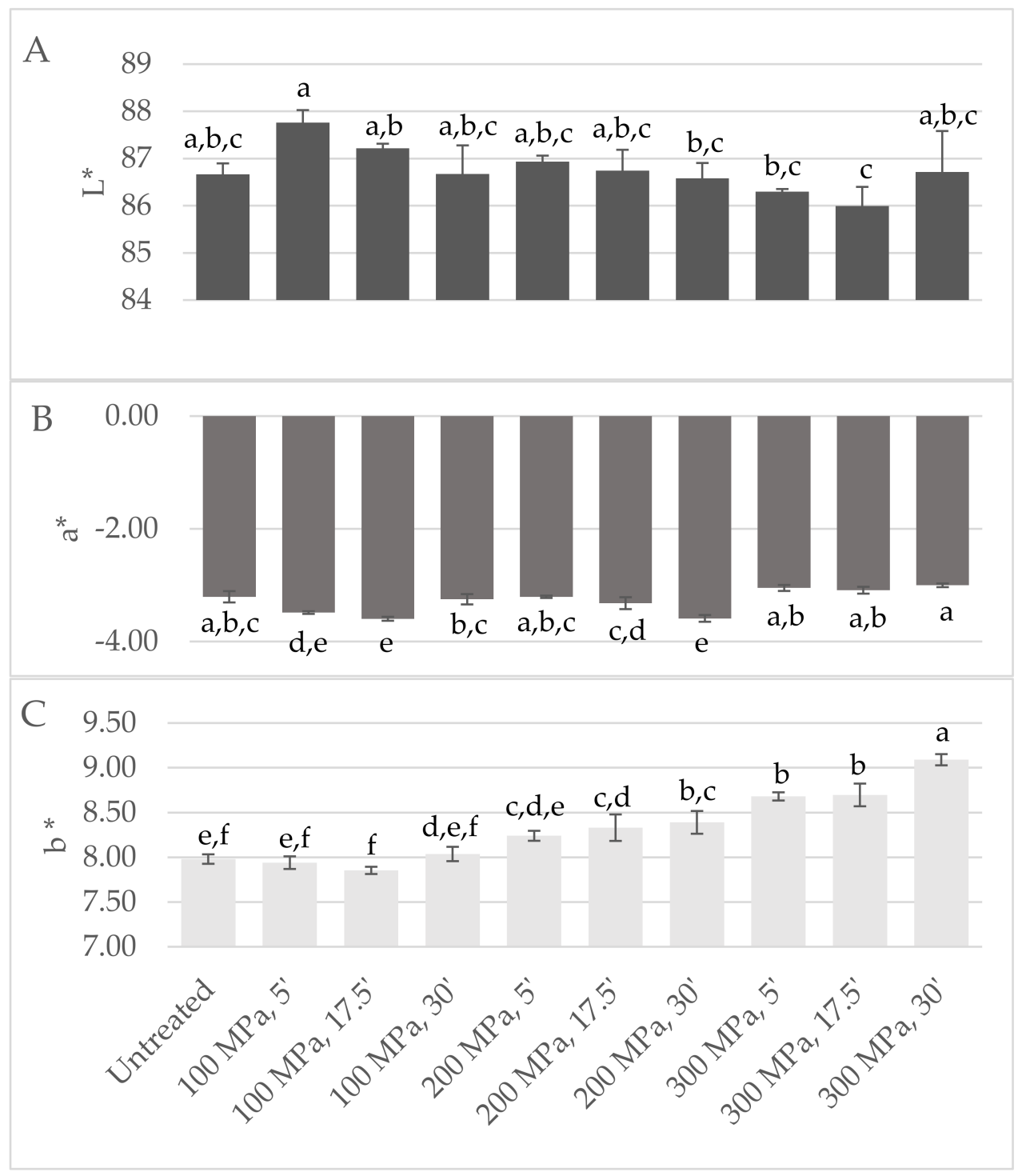

Figure 4. Design of experiment results: colour CIE (A) $L^{*},(\mathbf{B}) a^{*}$ and $(\mathbf{C}) b^{*}$ parameters measured in milk high-pressure processing (HPP) treated according to central composite design. Different non-capital letters $(\mathrm{a}, \mathrm{b}, \mathrm{c}, \mathrm{d}, \mathrm{e}, \mathrm{f})$ indicate statistically significant differences between the different conditions $(p<0.05)$.

HPP-treated milk resulted in curds (Figure S5) with increased yields between 5 and $24 \%$ in comparison to the control milk (Figure 5A), being the highest values achieved with milk treated at $300 \mathrm{MPa} / 17.5 \mathrm{~min}$. To the best of our knowledge, there is only one work that studied HPP application on ewes' milk, revealing a similar behaviour but reporting lower curd yields of about 5\% for HPP-treated ewes' milk at 200 and $300 \mathrm{MPa}$ for $30 \mathrm{~min}$, while at $100 \mathrm{MPa}$ a yield similar to untreated milk was verified $(10,20$ and $30 \mathrm{~min}$ of treatment time at $300 \mathrm{MPa}$ showed no effect on yield) [13]. In the present study, the model analysis of the results revealed that the effect of the studied variables on yield could be described by a linear model, where pressure has the greatest contribution $(p<0.03$ with lack of fit $p=0.067)$.

Since during the two previous screening studies it was visually observed that syneresis showed a clearly different behaviour among samples, syneresis was also studied (Figure 5B). Initially after centrifugation, minor whey release was quantified for curds obtained from HPP milk pre-treatment, particularly for treatments at 100 and $300 \mathrm{MPa}$ for $17.5 \mathrm{~min}$ (about 34 and 29\%, respectively, against 45\% for untreated milk), but syneresis after $24 \mathrm{~h}$ 
revealed lower, yet statistically insignificant, values for the control milk curds $(p>0.05)$. As previously mentioned, HPP may induce water retention in curd [11,26-28], a situation that appears to be related to a change in the structure of the para-caseinate network [26], an observation that may help explain the different syneresis behaviours observed for the HPP-treated samples. Relative to coagulation time, pre-treated HPP milk revealed at least $12 \%$ faster coagulation than untreated milk, as reported in the literature $[13,14,17,19]$.

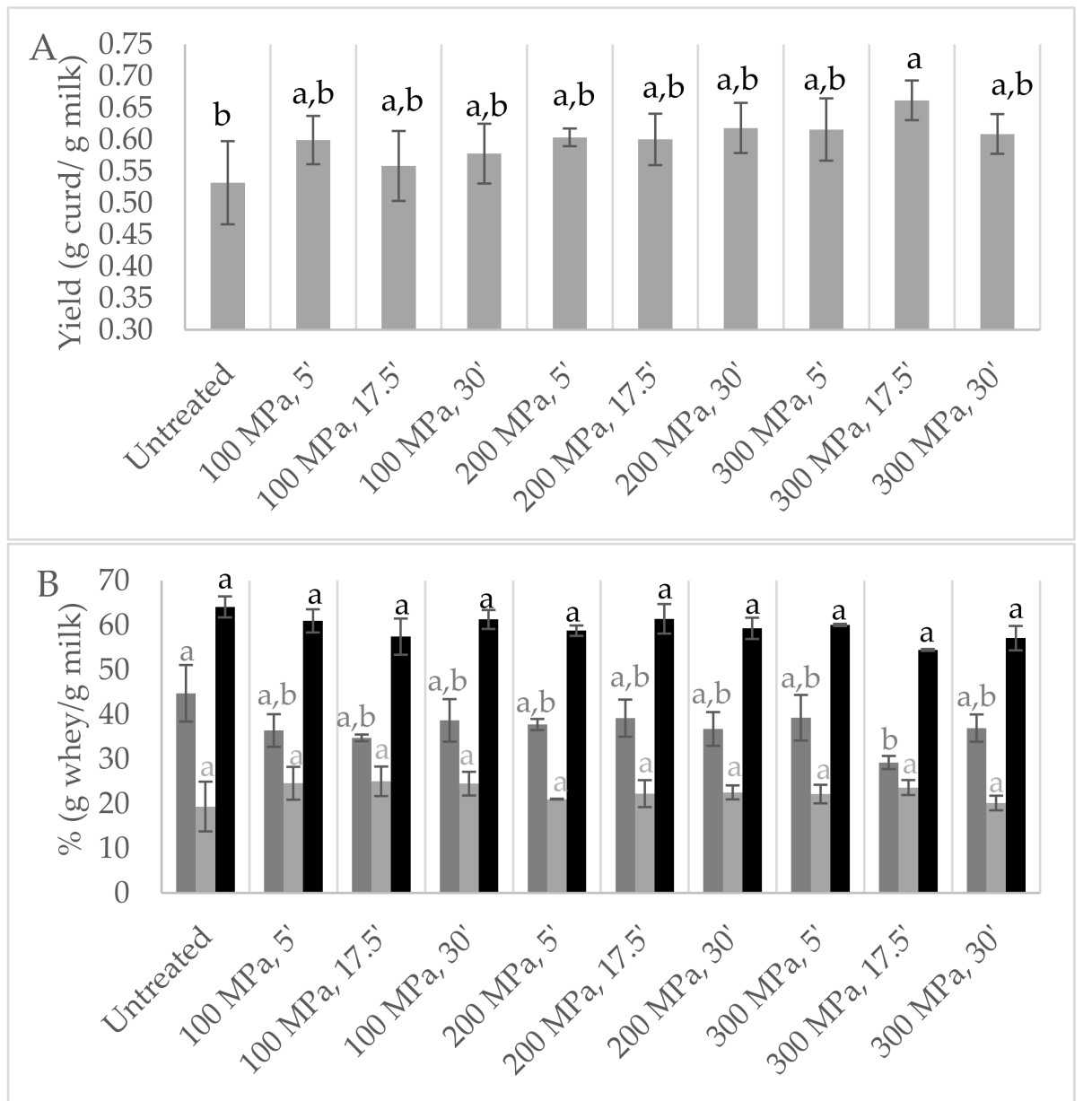

Figure 5. Design of experiment results: (A) yield expressed in g of curd per $\mathrm{g}$ of milk; $(\mathbf{B})$ whey release immediately after centrifugation: first whey $(\square)$; syneresis $(24 \mathrm{~h})(\square)$; whey + syneresis $(\boldsymbol{\square})$; from milk high-pressure processing (HPP)-treated according to central composite design. Control samples are untreated milk. Different non-capital letters $(a, b)$ indicate statistically significant differences between the different conditions $(p<0.05)$.

The $\mathrm{pH}$ values were also analysed in untreated and HPP pre-treated milk and in the curds obtained therefrom, as shown in Figure 6. HPP-treated milk revealed higher $\mathrm{pH}$ values (6.4-6.5) than the untreated milk (6.29), a trend even more noticeable in milk pressurized at the highest pressure intensity $(300 \mathrm{MPa})$, corroborating the results reported above, which can be justified by colloidal calcium phosphate solubilization [22]. Higher $\mathrm{pH}$ values were registered in curds resulting from HPP-treated milk (5.18-6.42) than untreated milk (5.13), being significantly higher in curd resulting from milk treated at $300 \mathrm{MPa}$ $(p<0.001)$ (Figure 6). Similarly, about $0.6 \mathrm{pH}$ units above that of the control cheese were reported for curd from HPP goat milk (400 MPa/5 min) [26]. However, higher intensity HPP treatments (586 MPa/1 min and 400-600 MPa/10 min) in bovine milk revealed no effect on curd $\mathrm{pH}$ [9] or led to a decrease [29]. 


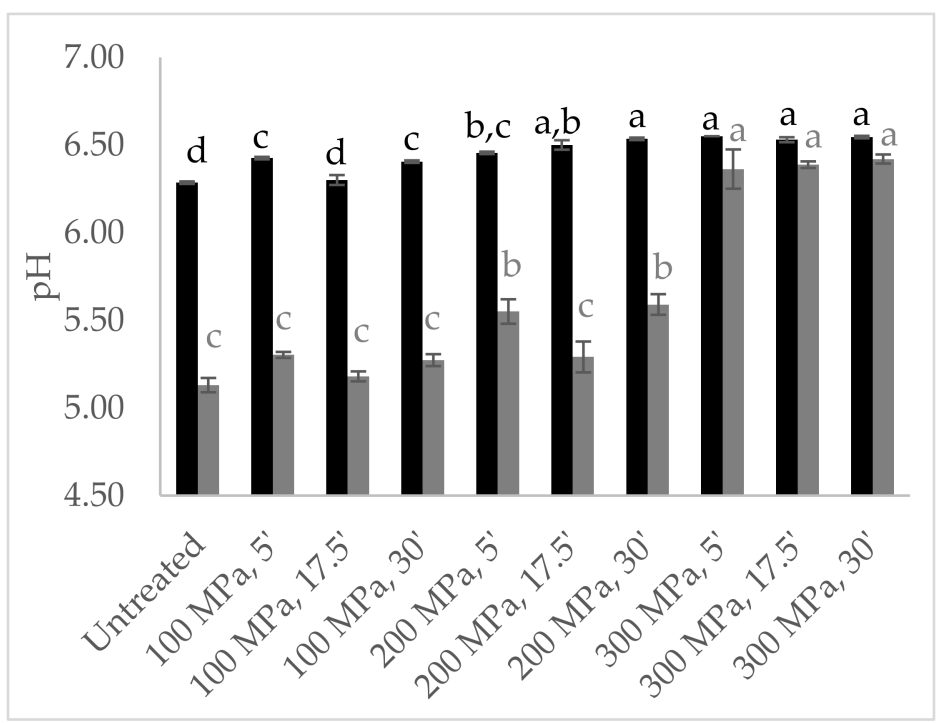

Figure 6. Design of experiment results: milk (ם) and curd ( $\square) \mathrm{pH}$ values from milk high-pressure processing (HPP)-treated according to central composite design. Different non-capital letters (a, b, c, d) indicate statistically significant differences between the different conditions $(p<0.05)$.

Milk microbiota viable cell numbers are shown in Figure 7. In untreated milk samples, lactobacilli, lactococci and enterococci were found at 7.25, 4.28 and $5.35 \log \mathrm{cfu} / \mathrm{mL}$, respectively (Figure 7A). Enterobacteriaceae and total coliform viable cell numbers were found to be at a similar level, 6.53 and $6.69 \log \mathrm{cfu} / \mathrm{mL}$, respectively. Escherichia coli and Staphylococcus spp. were detected at 4.34 and $4.48 \mathrm{log} \mathrm{cfu} / \mathrm{mL}$, respectively. Yeasts and moulds were detected at $5.63 \log \mathrm{cfu} / \mathrm{mL}$ (Figure $7 \mathrm{~B}$ ). As expected, a higher pressure intensity led to a higher microbial inactivation, particularly for longer holding times under pressure, as shown in Figure 7. Pressure lethal effect on micro-organisms was also reported to be higher as pressure increased from 100 to $300 \mathrm{MPa}$ for $30 \mathrm{~min}$ in bovine milk [18], having the total aerobic counts achieved at an approximately $0.9 \log$ reduction.

HPP has been reported as an alternative to traditional thermal pasteurization in order to increase the microbial milk quality, but then lactic starter cultures needed to be added. This is an approach not possible for PDO cheeses, such as Serra da Estrela cheese, since the use of starter cultures is not allowed, and so a balance between spoilage microbiota inactivation while keeping as much as possible of the beneficial microbiota was necessary and became one of the objectives of the present work. Drake et al. (1997), Buffa, Guamis, Royo and Trujillo (2001) and Trujillo et al. (1999) treated bovine and goat milks at $586 \mathrm{MPa} / 1 \mathrm{~min}$ and $500 \mathrm{MPa} / 15 \mathrm{~min}$, and the total viable cell numbers were reduced in $0.87-2.2 \log$ cycles, coliforms in $>1.3 \log$ cycles and Enterobacteriaceae $>1.9-3.8 \log$ cycles relativity to control milk. This same HPP treatment in goat milk led to lactobacilli reduction to below the quantification limit ( $>2.36 \log$ cycles) [30].

The design of experiment results analysis allowed for optimization of the desirability answers (Table 2). In what concerns the microbiota, viable cell number reduction data were normalized by dividing by the mean of the microbial load of the untreated samples, expressing the microbial inactivation percentage. The model was then optimized in order to have: (1) the minimum values of normalized logarithmic reductions of lactobacilli, lactococci and enterococci (this family was added as a group to benefit, since its relevance in the development of cheese flavour is well known), (2) the maximum values of normalized logarithmic reductions of Enterobacteriaceae, total coliforms, E. coli, staphylococci and yeasts and moulds (known to be spoilage micro-organisms) and (3) the highest yield possible.

In this analysis, it was taken into account that not all the microbial groups have equal relevance to cheese maturation. Different importance levels were considered in the optimization design of experiment analysis to determine the optimal conditions, as shown in Table 2. An equal relevance attribution revealed $288.38 \mathrm{MPa}$ for $5 \mathrm{~min}$ as the optimal HPP 
conditions. Considering the lactobacilli and lactococci values were fivefold more important, enterococci threefold more important and onefold for the other microbial groups under study, HPP treatment at $121.5 \mathrm{MPa}$ for $30 \mathrm{~min}$ was achieved as the optimum conditions (the predicted results using these conditions are shown in Figure 8).

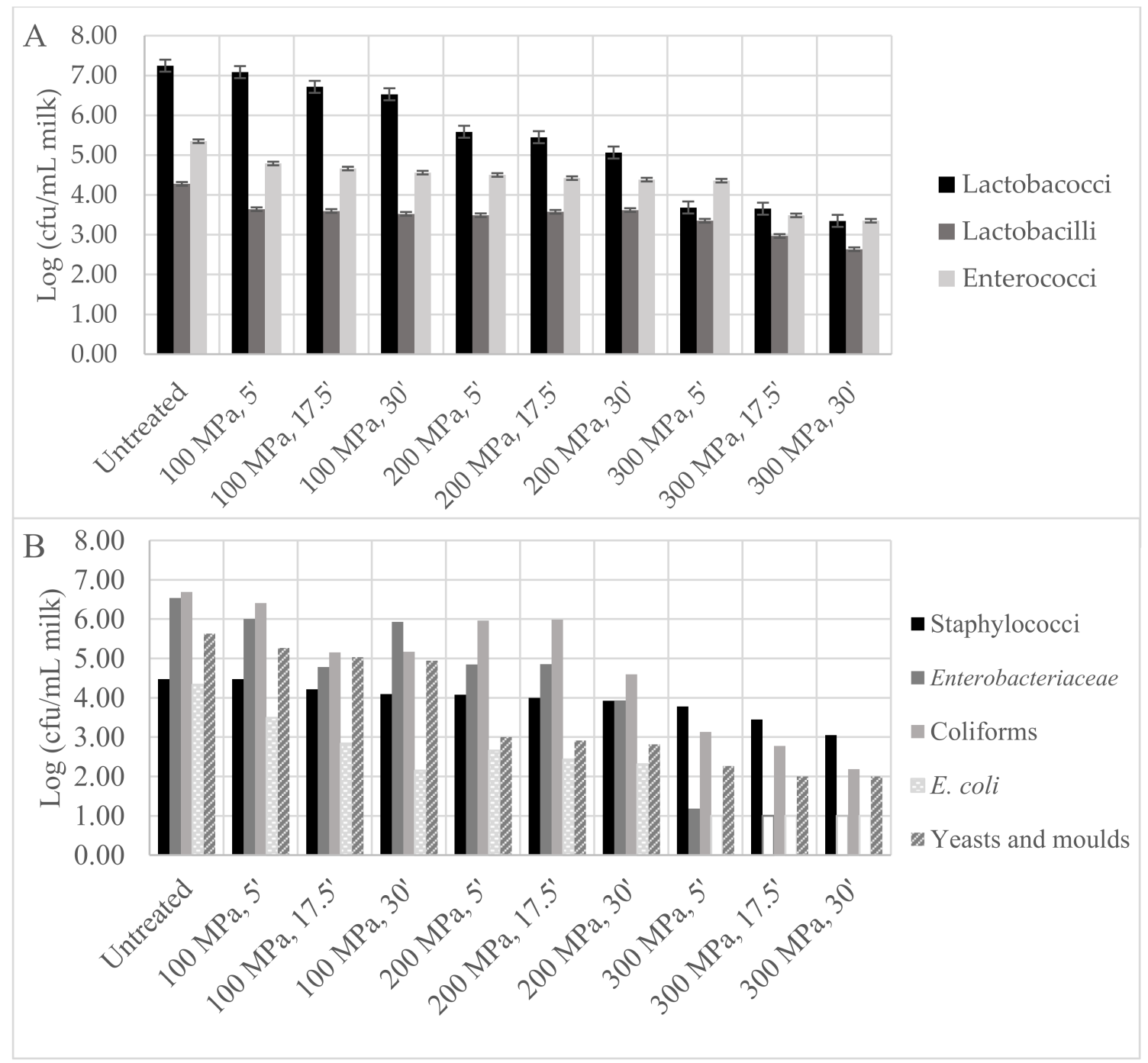

Figure 7. Design of experiment microbiota results: (A) lactobacilli, lactococci, enterococci and (B) staphylococci, Enterobacteriaceae, total coliforms, Escherichia coli and yeasts and moulds viable cell numbers in ewe milk samples after high-pressure processing (HPP) treatment according to central composite design. Empty bars represent microbial loads below the quantification limit $(1.0 \log \mathrm{cfu} / \mathrm{mL})$.

Table 2. Parameters considered in model optimization of the design of experiment (microbiota and yield) with response goals, with the respective different importance attributed and values expected to achieve by the modulation design at predicted optimized conditions.

\begin{tabular}{lccccccc}
\hline & Response Goal & Importance & Expected Value & Importance & Expected Value & $\begin{array}{c}\text { STD } \\
\text { Adjusted }\end{array}$ \\
\hline Lactococci & Low & 1 & 45.4 & 25 & 14.2 & 1.38 \\
\hline Lactobacilli & Low & 1 & 22.2 & 25 & 15.2 & 2.25 \\
\hline Enterococci & Low & 1 & 20.1 & 15 & 13.4 & 2.13 \\
\hline
\end{tabular}


Table 2. Cont.

\begin{tabular}{|c|c|c|c|c|c|c|}
\hline & Response Goal & Importance & Expected Value & Importance & Expected Value & $\begin{array}{c}\text { STD } \\
\text { Adjusted }\end{array}$ \\
\hline Enterobacteriaceae & High & 1 & 71.3 & 5 & 16.1 & 5.42 \\
\hline Coliforms & High & 1 & 45.4 & 5 & 23.2 & 4.05 \\
\hline Escherichia coli & High & 1 & 71.9 & 5 & 46.8 & 2.43 \\
\hline Staphylococci & High & 1 & 15.1 & 5 & 8.5 & 1.70 \\
\hline $\begin{array}{l}\text { Yeasts and } \\
\text { moulds }\end{array}$ & High & 1 & 61.1 & 5 & 20.9 & 1.98 \\
\hline Yield & High & 1 & 0.62 & & 0.58 & \\
\hline & Optimized & $\begin{array}{c}\mathrm{P} \\
(\mathrm{MPa})\end{array}$ & Time (min) & $\begin{array}{c}\mathrm{P} \\
(\mathrm{MPa})\end{array}$ & Time (min) & \\
\hline & & 288.4 & 5 & 121.5 & 30 & \\
\hline & Desirability & \multicolumn{2}{|c|}{0.59} & & 0.61 & \\
\hline
\end{tabular}

A

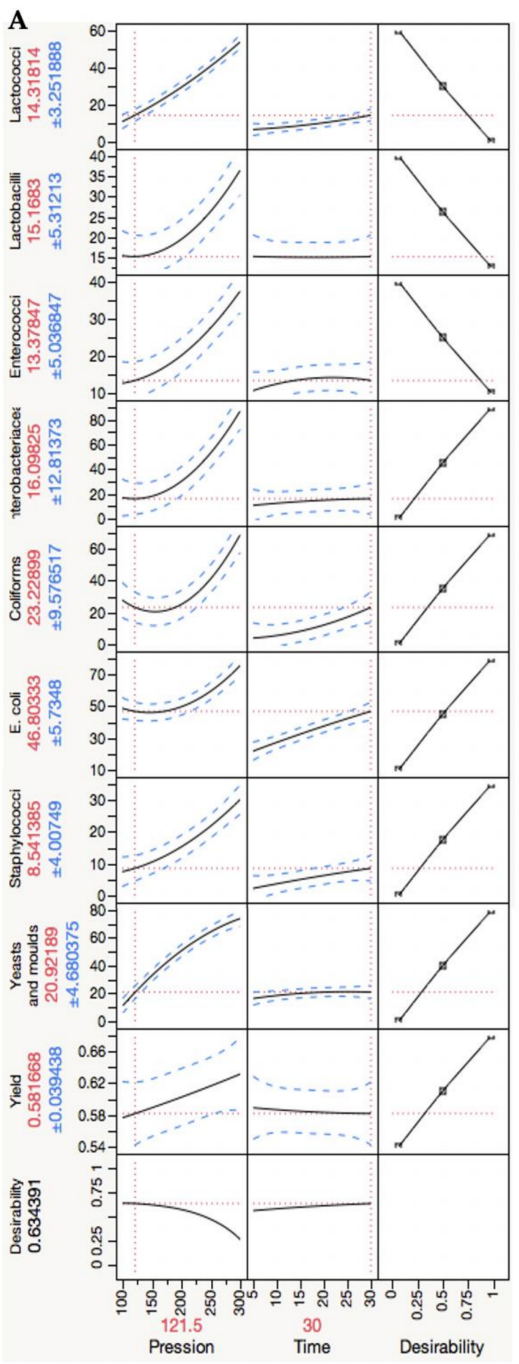

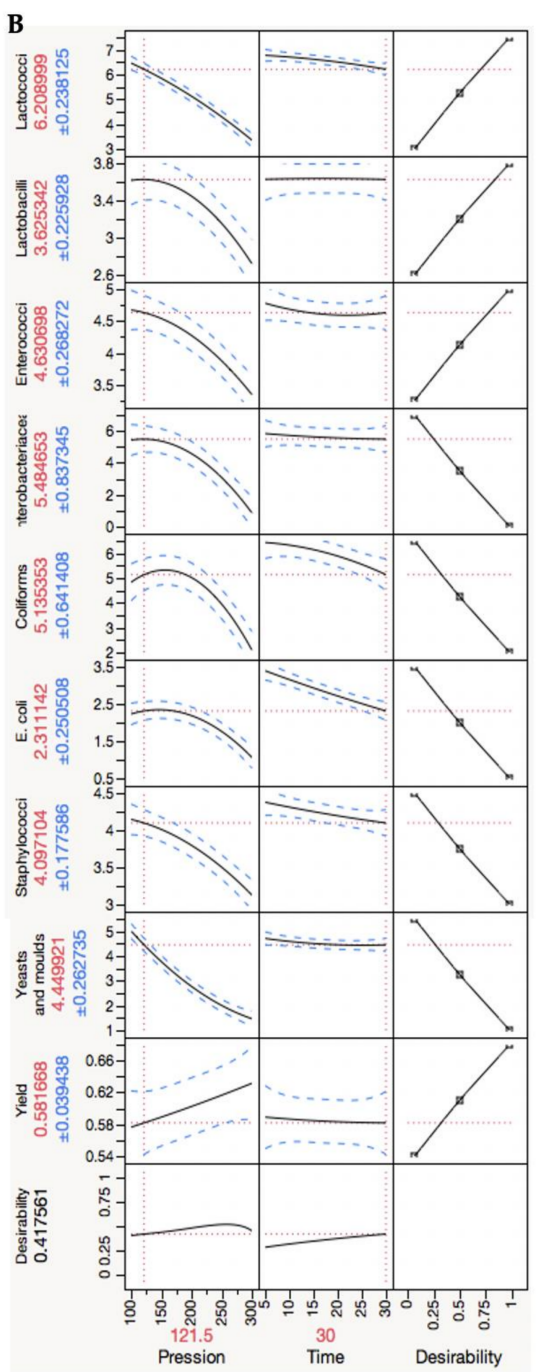

Figure 8. Design of experiment results: prediction profile of results optimization (by JMP9 software) of the surface model, assuming greater importance for lactobacilli and lactococci (quintuple of importance) and to enterococci (triple of importance). Equal importance was attributed to the remaining microbial groups/species. (A) Standard results are expressed in decimal reductions relative to the control load; (B) microbial viable cells numbers. 


\subsection{Model Validation}

The optimum condition obtained in the optimization study considering different importance levels, $121 \mathrm{MPa} / 30 \mathrm{~min}$, was subsequently applied to new batch of raw ewes' milk, in quintuplicate, for a greater robustness to validate the predicted results. Untreated milk was also studied to allow data normalization, and Table 3 and Figure S6 present all the obtained results: curd yield, microbiota viable cell numbers, whey quantification and $\mathrm{pH}$ values. Statistical analysis of all data obtained during model validation revealed that lactococci, lactobacilli, enterococci, Enterobacteriaceae, total coliforms and yeasts and moulds inactivation percentages $(p>0.05)$ were according to the predicted statistic prevision, thus validating these parameters (Table 3). However, E. coli and staphylococci inactivation was not validated $(p<0.05)$. Curd yield and released whey were also validated by the model $(p>0.05)$.

Thus, the HPP conditions $121 \mathrm{MPa}$ for $30 \mathrm{~min}$, when applied to raw ewes' milk within $24 \mathrm{~h}$ after collection and transformed within the next $24 \mathrm{~h}$ to curd, were validated as the optimal conditions to combine the best possible inactivation of spoilage microbial viable cells, with a very low reduction of viable cell numbers of beneficial microbiota, and simultaneously achieve a better curd yield. 
Table 3. Results for model validation: microbiota viable cell numbers were normalized and expressed in inactivation percentage (log reductions/log counts untreated milk samples). Prevision values and adjusted standard deviation determined by Minitab Software.

\begin{tabular}{|c|c|c|c|c|c|c|c|c|}
\hline & Lactococci & Lactobacilli & Enterococci & Enterobacteriaceae & Coliforms & Escherichia coli & Staphylococci & $\begin{array}{c}\text { Yeasts and } \\
\text { Moulds }\end{array}$ \\
\hline $121 \mathrm{MPa}, 30^{\prime}(\mathrm{A})$ & 11.37 & 15.06 & 13.11 & 25.57 & 22.27 & 43.14 & 27.32 & 19.34 \\
\hline $121 \mathrm{MPa}, 30^{\prime}(\mathrm{B})$ & 16.61 & 12.03 & 15.10 & 20.65 & 23.12 & 37.30 & 15.24 & 22.55 \\
\hline $121 \mathrm{MPa}, 30^{\prime}(\mathrm{C})$ & 12.55 & 15.95 & 12.01 & 23.02 & 22.82 & 44.64 & 22.68 & 23.27 \\
\hline $121 \mathrm{MPa}, 30^{\prime}(\mathrm{D})$ & 15.17 & 15.06 & 14.88 & 18.75 & 17.34 & 40.53 & 25.15 & 23.10 \\
\hline $121 \mathrm{MPa}, 30^{\prime}(\mathrm{E})$ & 12.55 & 15.42 & 15.56 & 12.68 & 21.59 & 39.41 & 23.23 & 24.00 \\
\hline STD (adjusted) & 1.38 & 2.25 & 2.13 & 5.42 & 4.05 & 2.43 & 1.70 & 1.98 \\
\hline \multirow{3}{*}{ IC $95 \%$} & 11.07 & 9.86 & 8.34 & 3.28 & 13.65 & 41.07 & 4.53 & 16.24 \\
\hline & 17.57 & 20.48 & 18.42 & 28.91 & 32.80 & 52.54 & 12.55 & 25.60 \\
\hline & Validated & Validated & Validated & Validated & Validated & Not validated & Not validated & Validated \\
\hline$p$-value & 0.278 & 0.645 & 0.432 & 0.096 & 0.325 & 0 & 0 & 0.083 \\
\hline
\end{tabular}




\section{Conclusions}

When screening the factors that affect curd yield, it is very important to test as many factors as possible in order to identify the significance of each of them. The experimental design allowed us to determine that the most influential factors on Serra da Estrela cheese production, from high-pressure-treated milk, were pressure intensity, holding time under pressure and time after HPP. A focused screening design was able to pinpoint that the viable cell numbers in milk HPP-treated at $400 \mathrm{MPa}$ were considerably affected, while the lower pressure intensity kept the beneficial microbiota and improved the curd yield. For the identification of optima, a response surface design was performed, and higher pressure intensity led to a higher microbial inactivation, which was more pronounced at longer holding times under pressure. Nevertheless, placing as the main target an equilibrium between the best inactivation levels for spoilage bacteria without hindering (lowest reduction possible) beneficial microbiota viable cell numbers, coupled to an increased yield, led to determining HPP milk pre-treatment at $121 \mathrm{MPa}$ for $30 \mathrm{~min}$ as the optimum condition, and model validation confirmed the predicted results.

In conclusion, HPP treatment of raw ewes' milk prior to cheese manufacture can enable Serra da Estrela curd yield increment and improve the microbial profile important from both safety and quality points of view.

Supplementary Materials: The following supporting information can be downloaded at: https: / /www.mdpi.com/article/10.3390/foods11030435/s1, Figure S1. First screening: curds obtained from milk HPP at different conditions: (A) after centrifugation and whey separation, $0 \mathrm{~h}$; (B) after $2 \mathrm{~h}$; (C) after 24 h; Figure S2. Second screening: milk bags (A) $1 \mathrm{~h}$ after HPP at 100, 200, 300 and $400 \mathrm{MPa}$ for $5 \mathrm{~min}$; (B) after $24 \mathrm{~h}$; Figure S3. Second screening: curds obtained from milk HPP at 100, 200, 300 and $400 \mathrm{MPa}$ for $5 \mathrm{~min}$ (A) $0 \mathrm{~h}$ after centrifugation and (B) after $24 \mathrm{~h}$; Figure S4. Surface Model: milk bags (A) before HPP treatment and (B) immediately after HPP treatments according to central composite design; Figure S5. Surface Model: curds obtained from HPP milk pre-treated according to central composite design (A) $0 \mathrm{~h}$ after centrifugation and (B) after $2 \mathrm{~h}$; Figure S6. Validation model: (A) yield expressed in $\mathrm{g}$ of curd/g of milk; (B) whey release immediately after centrifugation: first whey; syneresis (24 h); whey + syneresis; (C) milk and curd $\mathrm{pH}$ values from HPP milk pre-treated.

Author Contributions: Conceptualization, R.S.I., R.B., J.A.S. and A.M.P.G.; methodology, R.S.I., R.B., J.A.S. and A.M.P.G.; software, R.S.I.; validation, R.S.I., J.A.S. and A.M.P.G.; formal analysis, R.S.I., R.B., J.A.S. and A.M.P.G.; investigation, R.S.I., R.B., J.A.S. and A.M.P.G.; resources, J.A.S. and A.M.P.G.; data curation, R.S.I.; writing—original draft preparation, R.S.I.; writing—review and editing, R.S.I., R.B., J.A.S. and A.M.P.G.; supervision, J.A.S. and A.M.P.G.; funding acquisition, J.A.S. and A.M.P.G. All authors have read and agreed to the published version of the manuscript.

Funding: This research was funded by Fundação para a Ciência e a Tecnologia (FCT) through support for LAQV-REQUIMTE (FCT UIDB/50006/2020) and CBQF (UIDB/50016/2020) research units, through national founds and, where applicable, co-financed by the FEDER, within the PT2020 Partnership Agreement. Rita S. Inácio is also grateful for financial support from FCT through the fellowship grant SFRH/BD/96576/2013, as well as to Frulact S.A. through the mentoring program Comendador Arménio Miranda by Frulact Academy.

Institutional Review Board Statement: Not applicable.

Informed Consent Statement: Not applicable.

Data Availability Statement: Data is contained within the article.

Conflicts of Interest: The authors declare no conflict of interest.

\section{References}

1. Macedo, A.C.; Malcata, F.X. Technological optimization of the manufacture of Serra cheese. J. Food Eng. 1997, 31, 433-447. [CrossRef]

2. Freitas, A.C.; Malcata, F.X. Microbiology and biochemistry of cheeses with Appélation d'Origine Protegée and manufactured in the Iberian Peninsula from ovine and caprine milks. J. Dairy Sci. 2000, 83, 584-602. [CrossRef]

3. Inácio, R.S.; Gomes, A.M.P.; Saraiva, J.A. Serra da Estrela cheese: A review. J. Food Process. Preserv. 2020, 44, e14412. [CrossRef] 
4. Huppertz, T.; Hinz, K.; Zobrist, M.R.; Uniacke, T.; Kelly, A.L.; Fox, P.F. Effects of high pressure treatment on the rennet coagulation and cheese-making properties of heated milk. Innov. Food Sci. Emerg. Technol. 2005, 6, 279-285. [CrossRef]

5. Huppertz, T.; Fox, P.F.; Kelly, A.L. Effects of high pressure treatment on the yield of cheese curd from bovine milk. Innov. Food Sci. Emerg. Technol. 2004, 5, 1-8. [CrossRef]

6. Dhineshkumar, V.; Ramasamy, D.; Siddharth, M. High pressure processing technology in dairy processing: A review. Asian J. Dairy Food Res. 2016, 35, 87-95. [CrossRef]

7. Chawla, R.; Patil, G.R.; Singh, A.K. High hydrostatic pressure technology in dairy processing: A review. J. Food Sci. Technol. 2011, 48, 260-268. [CrossRef]

8. Trujillo, A.J.; Capellas, M.; Saldo, J.; Gervilla, R.; Guamis, B. Applications of high-hydrostatic pressure on milk and dairy products: A review. Innov. Food Sci. Emerg. Technol. 2002, 3, 295-307. [CrossRef]

9. Drake, M.A.; Harrison, S.L.; Asplund, M.; Barbosa-Canovas, G.V.; Swanson, B.G. High Pressure Treatment of Milk and Effects on Microbiological and Sensory Quality of Cheddar Cheese. J. Food Sci. 1997, 62, 843-860. [CrossRef]

10. San Martín-González, M.F.; Rodríguez, J.J.; Gurram, S.; Clark, S.; Swanson, B.G.; Barbosa-Canovas, G. V Yield, composition and rheological characteristics of cheddar cheese made with high pressure processed milk. LWT-Food Sci. Technol. 2007, 40, 697-705. [CrossRef]

11. Molina, E.; Álvarez, D.M.; Ramos, M.; Olano, A.; López-Fandiño, R. Use of high-pressure-treated milk for the production of reduced-fat cheese. Int. Dairy J. 2000, 10, 467-475. [CrossRef]

12. Trujillo, A.J.; Royo, C.; Guamis, B.; Ferragut, V. Influence of pressurization on goat milk and cheese composition and yield. In Proceedings of the Advances in High Pressure Bioscience and Biotechnology; Ludwing, H., Ed.; Springer: Berlin/Heidelberg, Germany, 1999; Volume 54, pp. 457-460.

13. López-Fandiño, R.; Olano, A. Cheese-making properties of ovine and caprine milks submitted to high pressures. Lait 1998, 78, 341-350. [CrossRef]

14. López-Fandiño, R.; Olano, A. Effects of High Pressures Combined with Moderate Temperatures on the Rennet Coagulation Properties of Milk. Int. Dairy J. 1998, 8, 623-627. [CrossRef]

15. Miles, A.A.; Misra, S.S.; Irwin, J.O. The estimation of the bactericidal power of the blood. J. Pathol. Bacteriol. 1938, 38, 732-749. [CrossRef] [PubMed]

16. AOAC Official Method 947.05 Acidity of Milk-Titrimetric Method 2002. Available online: http://www.eoma.aoac.org/methods/ info.asp?ID=22571 (accessed on 29 December 2021).

17. López-Fandiño, R.; Mercedes, R.; Olano, A. Rennet Coagulation of Milk Subjected to High Pressures. J. Agric. Food Chem. 1997, 45, 3233-3237. [CrossRef]

18. López-Fandiño, R.; Carrascosa, A.V.; Olano, A. The Effects of High Pressure on Whey Protein Denaturation and Cheese-Making Properties of Raw Milk. J. Dairy Sci. 1996, 79, 929-936. [CrossRef]

19. Zobrist, M.R.; Huppertz, T.; Uniacke, T.; Fox, P.F.; Kelly, A.L. High-pressure-induced changes in the rennet coagulation properties of bovine milk. Int. Dairy J. 2005, 15, 655-662. [CrossRef]

20. Huppertz, T.; Kelly, A.L.; Fox, P.F. High pressure-induced changes in ovine milk: Effects on casein micelles and whey proteins. Milk Sci. Int. 2006, 61, 394-397.

21. Needs, E.C.; Stenning, R.A.; Gill, A.L.; Ferragut, V.; Rich, G.T. High-pressure treatment of milk: Effects on casein micelle structure and on enzymic coagulation. J. Dairy Res. 2000, 67, 31-42. [CrossRef]

22. Schrader, K.; Buchheim, W.; Morr, C. High pressure effects on the colloidal calcium phosphate and the structural integrity of micellar casein in milk. I. High pressure dissolution of colloidal calcium phosphate in heated milk systems. Food/Nahrung 1997, 41, 133-138. [CrossRef]

23. Gervilla, R.; Ferragut, V.; Guamis, B. High Hydrostatic Pressure Effects on Color and Milk-Fat Globule of Ewe's Milk. J. Food Sci. 2001, 66, 880-885. [CrossRef]

24. Gaucheron, F.; Famelart, M.H.; Mariette, F.; Raulot, K.; Michela, F.; Le Graeta, Y. Combined effects of temperature and highpressure treatments on physicochemical characteristics of skim milk. Food Chem. 1997, 59, 439-447. [CrossRef]

25. Huppertz, T.; Fox, P.F.; Kelly, A.L. Properties of casein micelles in high pressure-treated bovine milk. Food Chem. 2004, 87, 103-110. [CrossRef]

26. Saldo, J.; McSweeney, P.L.H.; Sendra, E.; Kelly, A.L.; Guamis, B. Proteolysis in caprine milk cheese treated by high pressure to accelerate cheese ripening. Int. Dairy J. 2002, 12, 35-44. [CrossRef]

27. Trujillo, A.J.; Capellas, M.; Buffa, M.; Royo, C.; Gervilla, R.; Felipe, X.; Sendra, E.; Saldo, J.; Ferragut, V.; Guamis, B. Application of high pressure treatment for cheese production. Food Res. Int. 2000, 33, 311-316. [CrossRef]

28. Saldo, J.; Sendra, E.; Guamis, B. High Hydrostatic Pressure for Accelerating Ripening of Goat's Milk Cheese: Proteolysis and Texture. J. Food Sci. 2000, 65, 636-640. [CrossRef]

29. Voigt, D.D.; Donaghy, J.A.; Patterson, M.F.; Stephan, S.; Kelly, A.L. Manufacture of Cheddar cheese from high-pressure-treated whole milk. Innov. Food Sci. Emerg. Technol. 2010, 11, 574-579. [CrossRef]

30. Buffa, M.; Guamis, B.; Royo, C.; Trujillo, A.J. Microbiological changes throughout ripening of goat cheese made from raw, pasteurized and high-pressure-treated milk. Food Microbiol. 2001, 18, 45-51. [CrossRef] 